Enlighten: Jurnal Bimbingan Konseling Islam

Volume 1 No 2 (Juli-Desember 2018) Hlm:133-138

Tersedia online di http://journal.iainlangsa.ac.id/index.php/enlighten P-ISSN 2622-8912, E-ISSN 2622-8920

\title{
DESCRIPTION OF THE SELF ADJUSTMENT STUDENTS COMING FROM OUTSIDE THE PADANG CITY
}

\author{
Erfan Ramadhani \\ Program Studi Bimbingan dan Konseling Universitas PGRI Palembang \\ Email: erfankonselor@gmail.com
}

\begin{abstract}
This research is intended to reveal students who are from outside the city of Padang. This research uses qualitative with descriptive method through collecting data with interviews, observation, and documentation. After the data is obtained then it is done by using the steps as follows, Data Reduction, Data Presentation, and Conclusion Drawings. The informants of this study were one person from outside the city of Padang and one person from the city of Padang. The results of this study are: 1) on indicators that discuss personal difficulties that are difficult to understand, 2) on indicators of social communication prepared about difficult time in socializing. Suggestions in this study are expected for migrants to be able to socialize well and are expected to be able to speak the new language, so that communication can continue.
\end{abstract}

Keywords: Self-Adjustment, Outside the City of Padang

\section{PENDAHULUAN}

Sebagai makhluk sosial manusia sangat membutuhkan kehadiran orang lain. Hal tersebut dikarenakan manusia merupakan makhluk sosial yang tidak dapat melakukan apapun apabila tidak adanya bantuan dari sesama manusia. Agar interaksi berjalan lebih baik manusia diaharapkan mampu untuk menyesuaikan diri atau beradaptasi terhadap lingkungan fisik maupun lingkungan sosialnya, sehingga dapat menyatu di lingkungan tanpa memunculkan masalah pada dirinya maupun kepada orang lain. Manusia dapat dikatakana berhasil dalam menjalani kehidupannya sehari-hari apabila manusia tersebut mampu menyesuaikan dirinya dengan baik pada lingkungan.

Penyesuaian dapat didefinisikan sebagai interaksi yang kontiniu antara diri individu sendiri, dengan orang lain dan dengan dunia luar. Ketiga faktor ini secara langsung dapat mempengaruhi individu dengan orang lain dan hubungan tersebut saling berkaitan 
(Acocella \& Calhoun, 1990). Dari diri sendiri yaitu jumlah keseluruhan dari apa yang telah ada pada diri individu, tubuh, perilaku dan pemikiran serta perasaan. Proses penyesuaian diri pada manusia tidaklah mudah, hal ini karena didalam kehidupannya manusia terus dihadapkan pada pola-pola kehidupan baru dan harapan-harapan sosial baru. Periode penyesuaian diri ini merupakan suatu periode khusus dan sulit dari rentang hidup manusia. Manusia dalam kehidupan seharinya diharapkan mampu memainkan peran sosial yang baru, mengembangkan sikap-sikap sosial dan mengembangkan nilai-nilai sesuai dengan tuntutan yang dihadapi saat ini (Hurlock,1980).

Kegagalan penyesuaian diri banyak dialami oleh remaja, termasuk mahasiswa. Tidak sedikit mahasiswa yang tidak dapat menyesuaikan diri dengan baik dan mengakibatkan mahasiswa tersebut menjadi konsumen minuman yang memabukan, serta pengkonsumsi bahkan pengedar obat-obatan terlarang karena ketidak mampuan penyesuaian diri (Djuawarijah, 2005). Dari fenomena tersebut dapat disimpulkan bahwa penyesuaian diri pada mahasiswa sanggat didibutuhkan agar mahasiswa tersebut dapat menerima serta diterima di lingkungan yang baru.

Berdasarkan hasil pengamatan peneliti selama berada di lapangan terdapat banyak mahasiswa yang berasal dari luar kota Padang, sepertihalnya mahasiswa Pascasarjana Jurusan Bimbingan dan Konseling Universitas Negeri Padang. Dari sekian banyak mahasiswa yang ada, mahasiswa yang berasal diluar kota padang diantaranya mahasiswa dari Bukit Tinggi, Pesisir Selatan, Sumatera Utara (Medan), Bengkulu dan masih banyak lagi. Dari sekian banyak mahasiswa yang dari daerah lain yang merantau ke Kota Padang untuk berkuliah, maka tidak jarang mahasiswa tersebut mendapat hambatan untuk menyesuaikan diri dengan adanya fenomena tersebut maka perlunya ada pengkajian lebih mendalam berkaitan dengan penyesuaian diri mahasiswa yang berasal dari luar kota Padang.

\section{METODE PENELITIAN}

Penelitian ini dilaksanakan di Pondokan Nilam yang terletak di Jalan Belibis Blok F No. 07 Kecamatan Air Tawar barat Kota Padang dan Pondokan Bakti terletak di Jalan Patengangan Parupuk Tabing Kecamatan Air tawar Barat kota Padang. Selanjutnya informan penelitian ini adalah dua orang mahasiswa yang berasal dari luar kota Padang yaitu: satu orang mahasiswa yang berasal dari Bukit Tinggi dan satu orang mahasiswa yang berasal dari Medan.

Iskandar (2009:252) mengungkapkandata atau informasi yang menjadi bahan baku penelitian, untuk diolah merupakan data yang berwujud primer dan data sekunder. 
1. Data Primer

a. Observasi Partisipatif

b. Wawancara mendalam

2. Data Sekunder

Data sekunder merupakan data yang diperoleh melalui pengumpulan atau pengolahan data yang bersifat studi dokumentasi (analisi dokumen) berupa penelaahnya terhadap dokumen pribadi, resmi kelembagaan, referensi-referensi atau peraturan (literatur laporan, tulisan dan lain-lain yang memiliki relevansi dengan fokus permasalahan penelitian. Sumber data skunder dapat dimanfaatkan untuk menguji, menafsirkan bahkan untuk meramalkan tentang organisai tempat penelitian, data-data yang berhubungan dengan subjek yang diteliti serta dokumen yang berkaitan dengan penelitian.

Selanjutnya, Milles dan Huberman dalam Sugiyono (2012:243) mengemukakan bahwa aktivitas dalam analisis data kualitatif dilakukan secara interaktif dan berlangsung secara terus menerus sampai tuntas, sehingga datanya sudah jenuh.Akitivitas dalam analisis data, yaitu : 1) Data Reduction (Reduksi Data), 2) Data Display (Penyajian Data), Penarikan Kesimpulan.

\section{HASIL DAN PEMBAHASAN}

Penelitian yang telah dilaksanakan dengan judul gamaran penyesuaian diri mahasiswa yang berasal dari luar kota Padang. Berdasarkan data yang diperoleh oleh peneliti melalui observasi, wawancara. Maka peneliti akan menganalisa temuan yang ada dalam penelitian ini, peneliti menggunakan analisis deskriptif kualitatif dan data yang diperoleh baik melalui observasi, wawancara dari pihak-pihak yang mengetahui tentang data yang peneliti butuhkan. Adapun data yang akan dipaparkan dan dianalisa oleh peneliti adalah:

Bagaimanakah gambaran penyesuaian diri mahasiswa yang berasal dari luar kota Padang. Dari hasil wawancara kepada narasumber, serta melakukan observasi langsung, peneliti dapat mengetahui gambaran penyesuaian diri mahasiswa yang berasal dari luar kota Padang, mulai dari penyesuaian terhadap diri pribadi yang berkenaan dengan kemampuan individu menerima dirinya sendiri untuk mencapai hubungan yang harmonis dengan lingkungan sosialnya dan penyesuaian diri terhadap lingkungan sosial yang berkenaan dengan penyesuian diri terhadap lingkungan masyarakat, keluarga/Rumah, dengan orang yang berada di sekolah/kampus dan penyesianan diri dengan teman. 
a. Penyesuianan Pribadi

Dalam penyesuain diri pribadi untuk menerima diri dilingkungan yang baru hal yang dilakukan ialah menyapa orang yang berada di lingkungan tempat kita tinggal. Kendala yang dialami dalam penyesuaian diri pribadi untuk dapat menerima diri dilingkungan masyarakat ialah diri pribadi sendiri yang tertutup dengan lingkungan, pendiam dan juga dari segi bahasa yang berbeda menyebabkan komunikasi yang kurang pas.

b. Penyesuaian Sosial

1) Penyesuaian dengan masyarakat disekitar tempat tinggal

Hal yang dilakukan untuk penyesuaian diri dilingkungan masyarakat ialah menyapa orang-orang disekitar dan ikut serta dalam kegiatan lingkungan masyarakat sekitar. Kendala yang dialami dalam penyesuaian diri dengan masyarakat sekitar ialah waktu yang kurang untuk bersosialisasi serta bahasa yang kurang memahami.

2) Penyesuaian dengan keluarga/rumah

Penyesuaian didalam Rumah atau kost hal yang dilakukan ialah saling menyapa dan saling mengerti keadaan sesama temen satu rumah. Kendala yang dialami dalam penyesuaian diri dalam lingkungan rumah ialah soal bahasa dan latar belakang yang berbeda menyebabkan komunikasi kurang baik.

\section{3) Penyesuian di Sekolah/kampus}

Dalam penyesuaian diri dalam lingkungan kampus hal yang dilakukan ialah menyapa teman-teman yang berada dikampus, selanjutnya ikut serta dalam kegiatan kampus serta ikut berperan aktif dalam diskusi. Kendala yang dialami dalam penyesuian diri dilingkungan kampus terletak pada diri individu itu sendiri sepertihalnya dari segi sifat diri yang pendiam, tidak bisa berbahasa daerah yang didatangi tersebut.

4) Penyesuaian dengan teman

Cara penyesuain diri dengan teman ialah dengan cara menyapa, mengajak teman bergabung atau berkumpul bersama. Kendala dalam penyesuaian diri dengan teman ialah soal bahasa dan latar belakang yang berbeda, dan kondisi individu yang berbeda-beda pula.

\section{KESIMPULAN}

Dari peneliti yang dilakukan peneliti dengan judul "Gambaran Penyesuaian Diri Mahasiswa yang Berasal dari Luar Kota Padang”. Berdasarkan data yang di perloeh melalui mawancara serta observasi dapat peneliti simpulkan sebagai berikut:

a. Penyesuianan Pribadi 
Dalam penyesuain diri pribadi untuk menerima diri dilingkungan yang baru hal yang dilakukan ialah menyapa orang yang berada di lingkungan tempat kita tinggal. Kendala yang dialami dalam penyesuaian diri pribadi untuk dapat menerima diri dilingkungan masyarakat ialah diri pribadi sendiri yang tertutup dengan lingkungan, pendiam dan juga dari segi bahasa yang berbeda menyebabkan komunikasi yang kurang pas.

b. Penyesuaian Sosial

1) Penyesuaian dengan masyarakat disekitar tempat tinggal

Hal yang dilakukan untuk penyesuaian diri dilingkungan masyarakat ialah menyapa orang-orang disekitar dan ikut serta dalam kegiatan lingkungan masyarakat sekitar. Kendala yang dialami dalam penyesuaian diri dengan masyarakat sekitar ialah waktu yang kurang untuk bersosialisasi serta bahasa yang kurang memahami.

2) Penyesuaian dengan keluarga/rumah

Penyesuaian didalam Rumah atau kost hal yang dilakukan ialah saling menyapa dan saling mengerti keadaan sesama temen satu rumah. Kendala yang dialami dalam penyesuaian diri dalam lingkungan rumah ialah soal bahasa dan latar belakang yang berbeda menyebabkan komunikasi kurang baik.

3) Penyesuian di Sekolah/kampus

Dalam penyesuaian diri dalam lingkungan kampus hal yang dilakukan ialah menyapa teman-teman yang berada dikampus, selanjutnya ikut serta dalam kegiatan kampus serta ikut berperan aktif dalam diskusi. Kendala yang dialami dalam penyesuian diri dilingkungan kampus terletak pada diri individu itu sendiri sepertihalnya dari segi sifat diri yang pendiam, tidak bisa berbahasa daerah yang didatangi tersebut.

4) Penyesuaian dengan teman

Cara penyesuain diri dengan teman ialah dengan cara menyapa, mengajak teman bergabung atau berkumpul bersama. Kendala dalam penyesuaian diri dengan teman ialah soal bahasa dan latar belakang yang berbeda, dan kondisi individu yang berbeda-beda pula

\section{SARAN}

Adapun saran dalam penelitian ini adalah diharapkan untuk orang pendatang dapat bersosialisasi dengan baik dan diharapkan mampu beradaptasi dengan bahasa yang baru dikenalnya, sehingga komunikasi dapat berlangsung. Selanjutnya untuk masyarakat 
apabila ada orang baru yang datang sebaiknya diberikan pemahaman untuk mengunakan bahasa Indonesia terlebih dahulu agar pendatang tersebut dapat menjalin komunikasi.

\section{DAFTAR RUJUKAN}

Acocella, J. R., \& Calhoun, J. F. (1990). Psychology of adjustment human relationship (3th ed). New York: McGraw-Hill.

Djuawarijah, D. (2005). Hubungan antara tingkat religiusitas dengan penyesuaian diri mahasiswa FIAI agkatan 2002/2003 tahun pertama. Jurnal Fenomena, 3,2, 110-118. Yogyakarta: Universitas Islam Indonesia Yokyakarta.

Hurlock. E. B. (1980). Psikologi Perkembangan suatu pendekatan sepanjang rentang kehidupan edisi kelima. Jakarta Erlangga.

Iskandar. (2009). Metodelogi Penelitian Pendidikan dan Sosial. Jakarta: Gaung Persada Press.

Sugiyono. (2012). Metode Penelitian Kuantitatif, Kualitatif dan $R \& D$. Bandung: Alfabeta. 